\title{
Konsep diri orang dengan HIV dan AIDS (ODHA) yang menerima label negatif dan diskriminasi dari lingkungan sosial
}

Hasna Sarikusuma
Nur Hasanah*

\author{
Ika Herani \\ Universitas Brawijaya
}

\begin{abstract}
ABSTRAK
Penelitian ini melihat gambaran pemaknaan subjektif konsep-diri orang dengan HIV dan AIDS (ODHA) yang menerima label negatif dan diskriminasi dari lingkungan. Dengan menggunakan pendekatan kualitatif-fenomenologis, dua orang ODHA kami observasi dan wawancari secara mendalam. Data yang didapatkan menunjukkan hal-hal sebagai berikut: (1) Konsep-diri ODHA sangat dipengaruhi oleh lingkungan sosialnya, (2) ODHA mengalami pelabelan negatif oleh lingkungan sosialnya (e.g., mayat hidup, kutukan, aib), (3) ODHA mengalami berbagai bentuk diskriminasi (e.g., dijauhi keluarga, pemisahan peralatan makan, dikucilkan oleh warga kampung dan lingkungan kerja), (4) sebagai konsekuensi dari pemberian label negatif dan diskriminasi, ODHA memandang, berpikiran, dan merasa negatif terhadap diri (e.g., putus asa, depresi, tidak berharga, tidak berguna, tidak berdaya, menarik diri dari lingkungan, dan berkeinginan bunuh diri).
\end{abstract}

Kata kunci: Orang dengan HIV/AIDS, konsep diri, diskriminasi, labeling negatif

\section{Self-concept of people with HIV and AIDS (ODHA) who experience negative labelling and discrimination from their social environment}

\begin{abstract}
The present study examines self-concept of people with HIV and AIDS (ODHA) that experience negative labeling and discrimination by the environment. Through qualitativefenomenological approach, two ODHA was observed and interviewed in-depth. The data suggests: (1) ODHA's self-concept is largely affected by their social environment, (2) ODHA experienced negative labeling (e.g., walking-dead, cursed, condemned), (3) ODHA experienced forms of discrimination (e.g., distanced by family members, discrimination of food utensils, socialy excluded by villagers and co-workers), (4) as the consequence of negative labeling and discrimination, ODHA perceives, think, and feel negatively towards themselves (e.g., despair, depressed, worthless, useless, helpless, withdrawn, and suicidal).
\end{abstract}

Keywords: People with HIV/AIDS, self-concept, discrimination, negative labeling

\footnotetext{
* Korespondensi mengenai penelitian ini dapat dilayangkan kepada Nur Hasanah, melalui email: n.hasanah6874@ub.ac.id
} 
HIV (Human Immunodeficiency Virus) dan AIDS (Acquired Immuno Deficiency Syndrome) merupakan masalah global, termasuk di Indonesia. Di tahun 2011 yang lalu, data dari Badan Pengendalian Penyakit dan Penyehatan Lingkungan (BPPPL) mencatat 2001 kasus HIV dan AIDS yang terjadi di 59 Kabupaten di Indonesia (BPPPL, 2011). Bagi orang dengan HIV dan AIDS (ODHA), berbagai permasalahan kerap dihadapi, baik itu permasalahan fisik, maupun psikologis. Secara psikologis, berbagai penelitian di Indonesia telah menunjukkan dampak buruk HIV dan AIDS terhadap konsep-diri ODHA (e.g., Indrawati, 2011; Nasution, 2008; Sinaga, 2007; Sismulyanto, 2010). Meskipun telah ada beberapa penelitian tentang konsep-diri ODHA tersebut, belum ada penelitian, dalam pengetahuan kami, yang melihat bagaimana dampak pemberian label negatif dan diskriminasi yang dilakukan oleh lingkungan sosial terhadap konsep-diri ODHA. Dengan demikian, di dalam penelitian ini, kami berusaha mengeksplorasi dengan pendekatan kualitatiffenomenologis implikasi pemberian label negatif dan diskriminasi terhadap konsep-diri ODHA. Penelitian tentang konsep-diri pada ODHA ini penting untuk dilakukan karena berbagai penelitian sebelumnya telah menunjukkan bagaimana konsep-diri negatif seringkali bermuara pada kecemasan dan depresi (Feather, 1982; Kessler, Turner, \& House, 1988; Sheeran \& McCarthy, 1992). Di mana kecemasan dan depresi selanjutnya dapat berkonsekuensi buruk terhadap kesejahteraan hidup individu secara umum, bahkan dapat mengarah kepada aksi bunuh diri (Beskow, 1990).

\section{LANDASAN TEORI}

\section{Konsep-diri}

Konsep-diri merupakan identitas diri seseorang sebagai sebuah skema dasar yang terdiri dari kumpulan keyakinan dan sikap terhadap diri sendiri yang terorganisasi (Baron \& Donn, 2003). Konsep-diri merupakan pandangan individu mengenai siapa dirinya yang dapat diperoleh lewat informasi yang diberikan orang lain (Mulyana, 2006). Selanjutnya, pengetahuan tentang diri ini digunakan dalam mengintepretasikan informasi dan pengalaman, serta basis pengambilan tindakan dalam kehidupan sehari-hari (Sarwono, 2009). Dengan kata lain, konsep-diri merupakan penentu sikap individu dalam bertingkah laku (Ghufron \& Rini, 2010; Pudjijogyanti, 2004). Artinya apabila individu cenderung berpikir akan berhasil, maka hal ini merupakan kekuatan atau dorongan yang akan membuat individu menuju kesuksesan. Sebaliknya jika individu berpikir akan gagal, maka hal ini sama saja mempersiapkan kegagalan bagi dirinya.

Menurut pandangan Hurlock (2005) konsep-diri dibagi berdasarkan perkembangannya menjadi konsep-diri primer dan konsep-diri sekunder. Konsep-diri primer terbentuk berdasarkan pengalaman di rumah, berhubungan dengan anggota keluarga seperti orangtua dan saudara. Konsep-diri sekunder terbentuk berdasarkan lingkungan luar rumah seperti teman sebaya atau relasi sosial lainnya.

Konsep-diri juga dapat dikategorikan sebagai positif dan negatif (Calhoun \& Acocella, 1978). Konsep-diri positif adalah pemahaman dan penerimaan diri terhadap sejumlah fakta yang bermacam-macam sehubungan dengan diri. Individu yang memiliki konsep-diri positif akan merancang tujuan-tujuan sesuai dengan realitas, yaitu tujuan yang memiliki kemungkinan besar untuk dicapai, mampu mengahadapi kehidupan kedepannya serta menganggap bahwa hidup adalah proses penemuan (Gumanti, 2007). Sedangkan konsep-diri negatif, megacu pada Ghufron dan Rini (2010), di satu sisi dikarakteristikan dengan pandangan yang tidak stabil sehubungan dengan diri, yaitu individu tidak mengetahui secara pasti mengenai kekuatan, kelemahan, dan hal-hal yang dapat dihargai dalam hidupnya. Di sisi lain, seorang dengan konsep-diri negatif memiliki pandangan diri yang terlalu teratur, di mana ia tidak membiarkan penyimpangan dari seperangkat hukum yang dalam pikirannya merupakan cara hidup yang tepat. Orang-orang dengan konsep-diri negatif cenderung sensitif 
dan sulit menerima kritikan, responsif dan senang dengan pujian, berkecendrungan hiperkritis (e.g., mengeluhkan diri, mencela dan meremehkan orang lain), merasa tidak disenangi orang lain, dan bersikap pesimis dalam kompetisi.

\section{Pemberian label}

Pemberian label adalah suatu identitas yang diberikan oleh seseorang atau kelompok lain atas dasar atribut atau ciri-ciri sosial yang dimiliki. Identitas yang diberikan ini sifatnya membedakan seseorang atau kelompok tersebut (Mulyati, 2010). Istilah labeling merupakan pemberian label kepada seseorang atau kelompok atas ciri-ciri yang melekat pada dirinya. Ciri-ciri tersebut dapat berasal dari ciri fisik yang menonjol, penyakit menetap yang diderita, karakter seseorang, orientas seksual, ciri kolektif ras, etnik dan golongan (Roman \& Trice; Aztlan, 2009). Labeling merupakan penilaian yang diberikan berdasarkan ciri fisik yang dimiliki. Seseorang yang diberi label, akan cenderung berbuat seperti label yang diberikan kepadanya dan akan terkurung dalam label tersebut (Mulyati, 2010).

Pemberian label dapat berbentuk positif atau negatif. Baik label positif maupun negatif dapat mempengaruhi perilaku individu. Label Positif merupakan pemberian cap atau label yang mempunyai makna yang baik sehingga cenderung akan memberikan dampak positif bagi individu yang diberi label (Ganengwin, 2007). Salah satu contoh label positif adalah Individu yang dicap sebagai "orang yang baik" oleh lingkungan sekitarnya dan memperlakukannya sebagai orang yang baik. Individu tersebut akan berusaha bersikap seperti apa yang di cap orang terhadap dia yaitu menjadi orang yang baik. Hal ini terjadi karena individu tersebut merasa dihargai dan pada akhirnya labeling ini akan melekat cukup kuat dalam diri individu. Label negatif merupakan pemberian cap atau label yang mempunyai makna negatif sehingga cenderung akan memberikan dampak negatif bagi individu yang diberi label (Ganengwin, 2007). Label negatif diberikan kepada seseorang yang dianggap menyimpang dari norma umum. Teori labeling menyatakan bahwa label negatif diberikan untuk seseorang memiliki dampak besar pada kehidupan seseorang. Misalnya, jika anak terus-menerus disebut bodoh oleh orang tuanya, bahwa anak cenderung mengembangkan konsep-diri yang rendah, mengantisipasi kegagalan di banyak daerah (khususnya akademik), menempatkan usaha kecil di sekolah dan dalam interaksi kompetitif dengan orang lain dan akhirnya gagal. Contoh lainnya jika seorang gadis remaja mendapatkan reputasi sembarangan, orang dewasa dan teman sebaya mendapatkan pelabelan seperti itu maka gadisgadis lain kemudian melakukan pengucilan pada remaja yang mendapat label dan remaja laki-laki akan selalu memberikan ejekan. Dampak label negatif, yaitu menurunnya motivasi, kesulitan menyelesaikan tugas, menarik diri dari orang lain, ketidakmampuan mengatur keuangan, defisit perawatan diri, makan dan kebiasaan tidur yang kesemuanya dapat menguras konsentrasi dari keluarga. Konsentrasi keluarga yang terganggu ini menyangkut tentang beban keluarga, beban penyimpangan perilaku, hubungan keluarga dan aktivitas harian yang terganggu.

\section{Diskriminasi}

Diskriminasi mengandung arti perlakuan tidak seimbang terhadap sekelompok orang, yang pada hakekatnya adalah sama dengan kelompok pelaku diskriminasi. Menurut Baron \& Donn (2003) diskriminasi dapat berakar dari sikap implisit yang terpicu secara otomatis dan stereotip (sikap di mana individu tidak menyadarinya). Diskriminasi di Indonesia juga diatur dalam suatu susunan UUD, Secara formal pengertian diskriminasi diatur di dalam UU No. 39 Tahun 1999 tentang Hak Asasi Manusia. Pasal 1 ayat (3) undang-undang tersebut menyatakan:

\footnotetext{
"Diskriminasi adalah setiap pembatasan, pelecehan, atau pengucilan yang langsung ataupun tak langsung didasarkan pada pembedaan manusia atas dasar agama, suku, ras, etnik, kelompok, golongan, status sosial, status ekonomi, jenis kelamin, bahasa, atribut khas, keyakinan politik, yang
} 
berakibat pengurangan, penyimpangan, atau penghapusan pengakuan, pelaksanaan, atau penggunaan hak asasi manusia dan kebebasan dasar dalam kehidupan baik individual maupun kolektif dalam bidang politik, ekonomi, hukum, sosial, budaya dan aspek kehidupan lainnya".

Diskriminasi terhadap ODHA sering terjadi, khususnya dalam hal mendapatkan fasilitas kesehatan, di samping itu diskriminasi juga terjadi di lapangan pekerjaan dan pendidikan. ODHA seringkali diperlakukan tidak adil karena adanya ketakutan dari masyarakat untuk tertular penyakit tersebut, tidak semua RS (Rumah Sakit) mau menerima pasien yang terjangkit HIV DAN AIDS. Bentuk diskriminasi dari RS dan tenaga kesehatan adalah penolakan untuk merawat serta diskriminasi dalam pemberian perawatan sampai penolakan untuk memandikan jenazah. Perlakuan diskriminasi bisa terjadi di dalam keluarganya sendiri atau dalam masyarakat umum.

Bentuk diskriminasi dalam keluarga misalnya dengan dikucilkan, ditempatkan dalam ruang atau rumah terpisah padahal seharusnya keluarga adalah tempat utama dimana ODHA mendapat dukungan sehingga dapat memperpanjang usia dan kualitas hidup mereka. Diskriminasi dapat mengganggu kehidupan ODHA dengan mempengaruhi tekanan fisik, psikologi dan kehidupan sosial bahkan depresi. Seperti diketahui bahwa diskriminasi terhadap ODHA merupakan salah satu pelanggaran HAM yang paling mendasar, seperti hak untuk hidup bebas, hak atas privasi, serta hak untuk mendapatkan pelayanan kesehatan dan pendidikan (KPA Strategi Nasional Penanggulangan HIV DAN AIDS, 2007).

Diskriminasi terjadi di dunia kerja seperti adanya pemutusan hubungan kerja yang dilakukan oleh pemilik perusahaan kepada ODHA. Hal ini membuat UNAIDS (United Nations Programme on HIV DAN AIDS) melakukan tindakan intensif dengan memberdayakan ODHA melalui sebuah proyek percontohan mengenai mengembangkan akses menuju kewiraswastaan dan pelatihan membangun usaha untuk ODHA sendiri, yakni dengan cara melatih ODHA, memberi penyuluhan, sehingga ODHA dapat membuka usaha sendiri ketika para ODHA mendapatkan perilaku diskriminasi di lingkungan pekerjaan (KPA Strategi Nasional Penanggulangan HIV DAN AIDS, 2007).

\section{Konsep-diri ODHA, diskriminasi, dan pemberian label negatif}

Permasalahan yang dihadapi ODHA bukan hanya permasalahan kondisi fisik yang semakin menurun, namun juga timbul permasalahan sosial seperti penerimaan label negatif dan berbagai bentuk diskriminasi dari lingkungan. Penyakit HIV dan AIDS dianggap sebagai penyakit kutukan akibat perbuatan menyimpang karena penyakit HIV dan AIDS begitu melekat pada orang-orang yang melakukan penyimpangan seperti PSK (Pekerja Seks Komersial), gay, pelaku seks bebas dan pengguna narkoba suntik. Diskriminasi adalah perlakuan tidak seimbang terhadap perorangan atau kelompok berdasarkan sesuatu yang bersifat kategorikal. Perlakuan tidak seimbang yang diberikan pada ODHA disebabkan ODHA dianggap sebagai pembawa penyakit menular, berbahaya dan mematikan. ODHA akan menerima label negatif dan berbagai bentuk diskriminasi dari lingkungan seperti keluarga, teman, lingkungan sekitar karena sakit HIV dan AIDS yang diderita dianggap sebagai penyakit yang berbahaya dan mematikan bagi kalangan masyarakat.

Berdasarkan hasil interview peneliti, label negatif dan diskriminasi yang diterima ODHA mempengaruhi cara pandang ODHA terhadap dirinya atau konsep-diri. Konsep-diri merupakan pandangan individu mengenai siapa dirinya dan diperoleh melaluin informasi yang diberikan orang lain kepada dirinya (Mulyana, 2006). Label negatif dan bentuk diskriminasi dari lingkungan yang diterima oleh ODHA dijadikan sebagai informasi untuk menilai dirinya sendiri. Diskriminasi dan label negatif dapat mengganggu kehidupan ODHA dengan mempengaruhi tekanan fisik, psikologi dan kehidupan sosial bahkan depresi (KPA Strategi Nasional Penanggulangan HIV DAN AIDS, 2007). 
ODHA (Orang Dengan HIV DAN AIDS) seringkali mengadapi permasalahan yang komplek artinya mereka harus merasakan sakit di dalam tubuhnya yang semakin hari semakin menurun dan berbagai stigma tentang penyakit yang dideritanya dari lingkungan. Ketika ODHA berada di lingkungan termasuk keluarga dan lingkungan sosial maka ODHA seringkali merasa tidak tenang karena ODHA sadar bahwa lingkungan akan memberikan label negatif kepada dirinya atas sakit HIV DAN AIDS yang dideritanya. Lingkungan seringkali menganggap bahwa ODHA adalah seseorang yang mengidap penyakit kutukan karena perbuatan yang menyimpang, seseorang yang menderita penyakit berbahaya dan menular ataupun seseorang yang membawa aib buruk untuk keluarga dan orang yang dikenal. Pandangan seperti itu terjadi karena kurangnya pengetahuan tentang penyakit HIV DAN AIDS dan cara penularannya. Label negatif pada diri ODHA berkembang semakin kuat maka dalam waktu yang bersamaan akan menimbulkan diskriminasi pada ODHA. Lingkungan akan memberikan berbagai bentuk diskriminasi pada ODHA seperti penolakan melakukan perawatan untuk ODHA, pembedaan tempat makan, dikucilkan, mengisolasi dan pemutusan hubungan kerja. ODHA akan memiliki perbedaan cara pandang terhadap dirinya sebelum dinyatakan sebagai ODHA dan sesudah dinyatakan menderita HIV AIDS.

Berbagai bentuk label negatif dan diskriminasi dapat dijadikan bahan informasi bagi ODHA untuk dirinya sehingga mempengaruhi cara pandang atau konsep-diri ODHA. Berdasarkan hasil interview peneliti, ODHA yang menerima label negatif dan diskriminasi dari lingkungan cenderung akan membentuk konsep-diri negatif seperti putus asa, mengisolasi diri, bunuh diri namun tidak selamanya diskriminasi dan label negatif tersebut membentuk konsep-diri negatif. Label negatif diskriminasi yang diberikan pada ODHA juga dapat dijadikan motivasi bagi ODHA untuk bisa lebih baik dan menunjukkan pada lingkungan bahwa ODHA tidak layak menerima label negatif dan diskriminasi seperti yang telah mereka berikan pada ODHA.

\section{METODE}

\section{Partisipan}

Penelitian kualitatif ini melibatkan dua ODHA yang kami rekruit dengan menggunakan purposive sampling. Dengan teknik ini, kami memilih partisipan berdasarkan tujuan permasalahan penelitian yang kami kaji (lihat Iskandar, 2009). Di mana kami mengambil sejumlah kasus kecil dari kasus yang homogen (lihat Poerwandari, 2007). Kriteria pemilihan sampel yang kami gunakan adalah sebagai berikut:

- Dinyatakan positif mengidap penyakit HIV dan AIDS, berdasarkan hasil tes laboratorium dari pihak Rumah Sakit terkait.

- Pernah menerima bentuk label negatif dari lingkungan setelah dinyatakan positif HIV dan AIDS berdasarkan keterangan dari partisipan dan sumber data sekunder pada tahap wawancara.

- Pernah menerima bentuk diskriminasi dari lingkungan setelah dinyatakan positif HIV dan AIDS berdasarkan keterangan dari partisipan dan pihak-pihak terkait pada wawancara dan observasi tahap awal.

Partisipan pertama adalah laki-laki berinisial 'RD', berusia 42 Tahun, bekerja sebagai karyawan rumah sakit, dan telah didiagnosis HIV sejak tahun 2010. Partisipan ke-dua adalah perempuan berinisial ' $\mathrm{NK}$ ', berusia 38 tahun, tidak bekerja (ibu rumah tangga), dan telah didiagnosis HIV sejak tahun 2007.

\section{Desain penelitian}

Penelitian ini menggunakan pendekatan kualitatif-fenomenologis (lihat Iskandar, 2009; Poerwandari, 2007; Satori \& Aan, 2011). Teknik ini kami pilih untuk memahami para partisipan dan dunia pengalamannya. Data kami kumpulkan melalui tiga cara, yaitu 
observasi, wawancara, dokumentasi arsip. Sedangkan teknik analisis data kami lakukan dengan mengikuti langkah-langkah koding yng dijelaskan oleh Poerwandari (2007), yaitu secara berurutan, kami melakukan koding terbuka, aksial, dan selektif (untuk lebih jelas mengenai sistem koding ini, lihat Poerwandari, 2007).

\section{HASIL}

\section{Partisipan 1 (RD)}

\section{Kodifikasi terbuka}

Pada tahap analisis kodifikasi terbuka ini, kami mengidentifikasikan hal-hal yang muncul dari data observasi, wawancara, dan dokumentasi arsip ke dalam kategori-kategori. Kategorisasi ini dapat dilihat pada Tabel 1.

\section{Kodefikasi aksial}

Dalam tahap ini kami mengorganisasi data yang dihasilkan oleh kodefikasi terbuka dengan mengembangkan hubungan-hubungan di antara kategori-kategori atau di antara kategori dengan sub kategori di bawahnya (Poerwandari, 2007). Kodefikasi aksial partisipan 1 dapat dilihat pada Tabel 2.

Tabel 1. Kodifikasi terbuka partisipan 1

\begin{tabular}{|c|c|}
\hline Kategori & Properti \\
\hline $\begin{array}{l}\text { Asal label negatif dan } \\
\text { Diskriminasi }\end{array}$ & $\begin{array}{ll}\text { - } & \text { Istri } \\
\text { - } & \text { Saudara Kandung } \\
\text { - } & \text { Lingkungan kerja }\end{array}$ \\
\hline Bentuk Diskriminasi & $\begin{array}{ll}\text { - } & \text { Ditinggalkan istri } \\
\text { - } & \text { Dijauhi saudara kandung } \\
\text { - } & \text { Pemindahan kedudukan menjadi lebih rendah } \\
\text { - } & \text { Penempatan ruang kerja yang tidak layak } \\
\text { - } & \text { Pemisahan tempat dan ruangan makan } \\
\text { - } & \text { Penolakan dari karyawan lain }\end{array}$ \\
\hline Bentuk label negatif & $\begin{array}{ll}\text { - } & \text { Mayat Hidup } \\
\text { - } & \text { Aib } \\
\text { - } & \text { Pembawa penyakit menular }\end{array}$ \\
\hline $\begin{array}{l}\text { Penyebab terjadinya label } \\
\text { negatif dan diskriminasi }\end{array}$ & $\begin{array}{ll}\text { - } & \text { Takut tertular HIV } \\
\text { - } & \text { Pemikiran HIV penyakit yang mematikan } \\
\text { - } & \text { Pemikiran HIV penyakit menular dan berbahaya }\end{array}$ \\
\hline $\begin{array}{l}\text { Dampak label negatif dan } \\
\text { diskriminasi }\end{array}$ & $\begin{array}{ll}\text { - } & \text { Sering menyendiri } \\
\text { - } & \text { Ekspresi Wajah: } \\
\text { - } & \text { Marah } \\
\text { - } & \text { Menangis } \\
\text { - } & \text { Menundukkan kepala } \\
\text { Tersenyum }\end{array}$ \\
\hline $\begin{array}{l}\text { Asal label negatif dan } \\
\text { Diskriminasi }\end{array}$ & $\begin{array}{ll}\text { - } & \text { Istri } \\
\text { - } & \text { Saudara Kandung } \\
\text { - } & \text { Linqkunaan keria }\end{array}$ \\
\hline
\end{tabular}

Berdasarkan Tabel 2, kondisi penyebab (causal condition) penentuan konsep-diri partisipan pertama adalah perlakuan negatif dari keluarga, lingkungan kerja, dan teman sebaya, label negatif yang diterima selama menjadi ODHA, dan kurangnya dukungan sosial. Faktor pembentuk konsep-diri partisipan pertama dapat dilihat melalui bentuk perilaku, 
penilaian tentang dirinya sendiri, perasaan dan pemikiran yang seringkali timbul, dan cara merespon diskriminasi dan label negatif yang diterimanya.

Tahapan selanjutnya adalah konsekuensi (consequences) yang diterima oleh partisipan sebagai ODHA dalam kaitan penerimaan label negatif dan diskriminasi dari lingkungan. Konsekuensinya adalah seringkali timbul pemikiran yang negatif, mudah putus asa, berperilaku negatif seperti menyendiri, stres, dan penilaian diri yang rendah. Dalam menghadapi konsekuensi tersebut partisipan melakukan strategi (strategies), seperti berusaha menyibukkan diri, berkendaraan sendiri untuk mencari suasana baru, berkunjung ke kos di kota Malang karena partisipan cukup merasa nyaman berada di kosnya.

Tahapan konteks (context) merupakan situasi tertentu atau isu-isu yang menguatkan dalam proses penentuan konsep-diri partisipan. Konteks antara lain meliputi informasi negatif yang seringkali diterima tentang ODHA sebagai pembawa aib buruk, tidak mampu bertahan lama dan adanya banyak penolakan pada ODHA terutama bidang pekerjaan. Pada tahap hambatan (intervening condition) partisipan tidak mampu keluar dari tempat ia bekerja karena beban kebutuhan yang banyak sehingga proses diskriminasi dan label negatif yang diterima semakin kuat, tidak adanya dukungan dari pihak manapun sehingga partisipan tidak mampu menemukan solusi dalam permasalahannya.

Tabel 2. Kodefikasi aksial partisipan 1

\begin{tabular}{|c|c|}
\hline Causal Condition & Central Phenomenon \\
\hline $\begin{array}{l}\text { - } \quad \text { Perlakuan negatif dari lingkungan seperti keluarga, } \\
\text { lingkungan kerja, dan teman sebaya } \\
\text { - } \quad \text { Label negatif yang diterima selama menjadi ODHA } \\
\text { - } \quad \text { Tidak adanya dukungan dari siapapun } \\
\text { - Hidup sendiri }\end{array}$ & $\begin{array}{l}\text { Label negatif dan diskriminasi yang diterima ODHA } \\
\text { menentukan konsep-diri yang dimiliki: } \\
\text { - } \quad \text { Bentuk perilaku ODHA } \\
\text { - } \quad \text { Penilaian ODHA tentang dirinya } \\
\text { - } \quad \text { Perasaan dan pemikiran yang timbul } \\
\text { - Cara merespon diskriminasi dan label negatif } \\
\quad \text { yang diterima }\end{array}$ \\
\hline Consequences & Strategies \\
\hline $\begin{array}{l}\text { - } \quad \text { Timbulnya pemikiran yang negatif } \\
\text { - } \quad \text { Mudah putus asa } \\
\text { - } \quad \text { Berperilaku negatif seperti menyendiri dan tidak } \\
\text { - } \quad \text { Stres bersosialisasi } \\
\text { - } \quad \text { Penilaian diri yang rendah }\end{array}$ & $\begin{array}{l}\text { - } \quad \text { Berusaha menyibukkan diri seperti mencuci } \\
\text { baju, bersih-bersih, menyetrika baju } \\
\text { - } \quad \text { Berkunjung di kost kota Malang } \\
\text { - } \quad \text { Mengurung di kamar }\end{array}$ \\
\hline
\end{tabular}

Context

Intevening condition

- Informasi negatif yang seringkali didengar tentang ODHA bahwa manusia yang hanya bisa membawa aib buruk

- Informasi dari lingkungan sosial seringkali menyebut bahwa ODHA tidak dapat bertahan hidup lama

- Informasi yang menyatakan bahwa banyaknya penolakan dari berbagai pihak terhadap ODHA terutama pada bidang pekerjaan.

\section{Kodefikasi selektif}

Partisipan menerima label negatif dan diskriminasi semenjak dinyatakan mengidap HIV. Label negatif dan diskriminasi yang diterima oleh partisipan berasal dari berbagai lingkungan seperti istri, saudara kandung, lingkungan kerja dan teman sebaya. Konsep-diri merupakan pengetahuan dan penilaian tentang diri sendiri, sedangkan konsep-diri ini dapat diperoleh melalui informasi dan perlakuan orang lain terhadap dirinya. Informasi dan perlakuan negatif 
yang diterima partisipan memberikan dampak tidak baik bagi partisipan yang cenderung mengarah ke negatif.

Dampak dari label negatif dan diskriminasi yang diterima partisipan mempengaruhi penentuan konsep-diri partisipan yang meliputi perilaku, pemikiran, perasaan dan kebiasaan. Partisipan menjadi seseorang yang pendiam, tidak mau bersosialisasi atau menarik diri dari lingkungan, selalu berpikiran negatif, merasa bahwa dirinya paling buruk, mudah putus asa dan selalu muncul keinginan untuk mati. Hal ini semakin kuat karena tidak adanya dukungan dari berbagai pihak terutama keluarga sehingga partisipan harus menanggung beban seorang diri dan mengarah pada penilaian diri yang negatif.

\section{Partisipan 2 (KN)}

\section{Kodefikasi terbuka}

Pada tahap analisis kodifikasi terbuka ini, kami mengidentifikasikan hal-hal yang muncul dari data observasi, wawancara, dan dokumentasi arsip ke dalam kategori-kategori. Kategorisasi ini dapat dilihat pada Tabel 3.

Tabel 3. Kodefikasi terbuka partisipan 2

\begin{tabular}{|c|c|}
\hline Kategori & Properti \\
\hline Ekspresi & $\begin{array}{ll}- & \text { Sedih } \\
- & \text { Marah } \\
- & \text { Menangis } \\
- & \text { Menundukkan kepala }\end{array}$ \\
\hline Asal Label negatif dan Diskriminasi & $\begin{array}{ll}\text { - } & \text { Saudara Kandung } \\
\text { - } & \text { Rumah Sakit } \\
\text { - } & \text { Warga Kampung }\end{array}$ \\
\hline Bentuk Label negatif & $\begin{array}{ll}\text { - } & \text { Aib } \\
\text { - } & \text { Penyakit kutukan } \\
\text { - } & \text { Penyakit menular }\end{array}$ \\
\hline Bentuk Diskriminasi & $\begin{array}{l}\text { - } \quad \text { Penolakan keluarga } \\
\text { - } \quad \text { Penolakan warga kampung } \\
\text { - } \quad \text { Perlakuan kurang baik dari rumah sakit }\end{array}$ \\
\hline $\begin{array}{l}\text { Penyebab terjadi label negatif dan } \\
\text { diskriminasi }\end{array}$ & $\begin{array}{ll}\text { - } & \text { Takut tertular } \\
\text { - } & \text { Pemikiran HIV penyakit yang berbahaya dan mematikan } \\
\text { - } & \text { Pemikiran HIV sebagai penyakit orang-orang kotor }\end{array}$ \\
\hline $\begin{array}{l}\text { Dampak Label negatif dan } \\
\text { Diskriminasi }\end{array}$ & $\begin{array}{ll}\text { - } & \text { Menarik diri dari lingkungan } \\
\text { - } & \text { Putus Asa } \\
\text { - } & \text { Perasaan tertekan } \\
\text { - } & \text { Suka memberontak } \\
\text { - } & \text { Pendiam } \\
\text { - } & \text { Muncul pemikiran negatif }\end{array}$ \\
\hline
\end{tabular}

\section{Kodefikasi Aksial}

Tabel 4 menjelaskan beberapa kondisi yang dapat digunakan untuk melihat saling keterkaitan antara kategori-kategori di kodefikasi aksial. Penyebab (causal condition) konsep-diri partisipan adalah perlakuan negatif dari keluarga, rumah sakit, dan warga kampung. Fenomena utama dari fokus penelitian ini adalah penentuan konsep-diri ODHA yang menerima berbagai bentuk label negatif dan diskriminasi. Ini dapat dilihat melalui perilaku, penilaian, perasaan dan pemikiran yang seringkali timbul serta cara merespon partisipan ketika menerima label negatif dan diskriminasi.

Konsekuensi dari diskriminasi dan label negatif yang diterima ODHA antara lain munculnya pemikiran negatif, mudah putus asa, tidak mau bersosialisasi dengan warga kampung, pendiam, perasaan tertekan, memberontak dan penilaian diri yang rendah. Setelah 
adanya konsekuensi maka dilanjutkan dengan strategi sebagai upaya partisipan untuk mengurangi konsekuensi antara lain ibadah seperti sholat, mengurung diri di kamar, bercanda dengan anak, berkendaraan sendiri keluar rumah untuk mencari suasana baru.

Tahapan context merupakan situasi tertentu atau isu-isu yang menguatkan dalam proses penentuan konsep-diri partisipan antara lain informasi yang menyatakan bahwa ODHA sebagai pembawa aib buruk, Isu pengusiran partisipan dari kampung dan informasi yang menyatakan bahwa HIV merupakan penyakit kutukan dari orang-orang kotor.

Tahapan selanjutnya adalah Intervening condition atau hambatan bagi partisipan untuk memiliki konsep-diri yang baik, hambatan tersebut adalah status anak partisipan yang juga positif HIV, tidak adanya dukungan keluarga, tetap berada di kampung yang mengucilkan partisipan karena status HIV nya.

\section{Kodefikasi selektif}

Semenjak dinyatakan HIV partisipan menerima label negatif dan diskriminasi dari berbagai pihak seperti penolakan keluarga, penolakan warga kampung, perlakuan tidak baik dari rumah sakit, dianggap sebagai aib yang buruk dan penderita penyakit kutukan. Partisipan juga memiliki anak yang positif menderita HIV maka bukan hanya partisipan yang menerima diskriminasi namun keduanya yaitu partisipan dan anaknya. Label negatif dan diskriminasi yang partisipan terima dari lingkungan menentukan sikap dan pemikiran partisipan tentang dirinya. Konsep-diri diperoleh melalui informasi dan perlakuan orang lain terhadap dirinya, selama menjadi ODHA partisipan selalu menerima perlakuan dan informasi yang bersifat negatif tentang dirinya.

Tabel 4. Kodefikasi aksial partisipan 2

\begin{tabular}{|c|c|}
\hline Causal Condition & Central Phenomenon \\
\hline $\begin{array}{ll}\text { - } & \text { Perlakuan negatif dari lingkungan seperti } \\
\text { keluarga, rumah sakit dan warga kampung } \\
\text { - } \quad \text { Label negatif yang diterima selama menjadi } \\
\text { ODHA } \\
\text { - } \quad \text { Menjadi single parent dari ADHA (Anak Dengan } \\
\text { HIV AIDS) }\end{array}$ & $\begin{array}{l}\text { Label negatif dan diskriminasi yang diterima ODHA } \\
\text { menentukan konsep-diri yang dimiliki } \\
\text { Dimensinya : } \\
\text { - } \quad \text { Bentuk perilaku ODHA } \\
\text { - } \quad \text { Penilaian ODHA tentang dirinya } \\
\text { - } \quad \text { Perasaan dan pemikiran yang timbul } \\
\text { - } \quad \text { Cara merespon diskriminasi dan label negatif } \\
\quad \text { yang diterima }\end{array}$ \\
\hline Consequences & Strategies \\
\hline $\begin{array}{ll}\text { - } & \text { Timbulnya pemikiran yang negatif } \\
\text { - } & \text { Mudah putus asa } \\
\text { - } & \text { Tidak mau bersosialisasi di lingkungan } \\
\text { - } & \text { kampungnya } \\
\text { - } & \text { Berasaan tertekan memberontak } \\
\text { - } & \text { Dikucilkan dari kampung } \\
\end{array}$ & $\begin{array}{ll}\text { - } & \text { Berkendaraan sendirian untuk mencari suasana } \\
& \text { baru } \\
\text { - } & \text { lbadah } \\
\text { - } & \text { Bercanda dengan anak }\end{array}$ \\
\hline \multicolumn{2}{|l|}{ Context } \\
\hline $\begin{array}{l}\text { - Informasi negatif yang seringkali di dengar } \\
\text { tentang ODHA bahwa manusia yang hanya bisa } \\
\text { membawa aib buruk } \\
\text { - Informasi dari orang-orang yang seringkali di } \\
\text { dengar bahwa ODHA merupakan penyakit } \\
\text { kutukan dari orang-orang kotor } \\
\text { - Isu yang menyatakan bahwa partisipan akan } \\
\text { diusir dari kampung }\end{array}$ & $\begin{array}{l}\text { - } \quad \text { Status HIV yang bukan hanya dimiliki partisipan } \\
\text { namun juga dimiliki oleh anak partisipan. } \\
\text { Tidak adanya dukungan dari keluarga sehingga } \\
\text { partisipan kurang mampu menemukan solusi } \\
\text { dari permasalahannya. } \\
\text { - Ketidakmampuan partisipan untuk berpindah } \\
\text { tempat tinggal karena tidak adanya biaya untuk } \\
\text { pindah tempat tinggal sehingga diskriminasi } \\
\text { dan label negatif semakin kuat }\end{array}$ \\
\hline
\end{tabular}

Dampak label negatif dan diskriminasi yang diterima oleh partisipan bersifat negatif seperti mudah putus asa, tidak mau bersosialisasi, memberontak, pendiam, munculnya pemikiran negatif dan penilaian diri yang rendah. Alasan partisipan tidak mau bersosialisai 
dengan lingkungan karena adanya ketakutan dalam diri partisipan apabila semakin kuat pemberian diskriminasi dan labeling dari lingkungan kepada dirinya. Hal ini semakin kuat juga karena tidak adanya dukungan dari keluarga akan permasalahan yang dihadapi sehingga partisipan merasa hanya hidup dengan anaknya.

\section{KESIMPULAN}

Berdasarkan analisis yang telah dilakukan beberapa kesimpulan dapat ditarik:

1. Konsep-diri ODHA terbentuk melalui hasil interaksi sosial dengan lingkungan sekitarnya seperti istri, keluarga, teman dan orang lain.

2. Label negatif yang diterima kedua partisipan dari lingkungan adalah mayat hidup, pembawa penyakit menular, penyakit kutukan dan aib untuk lingkungan sekitar. Label negatif yang diterima oleh kedua partisipan membuat partisipan cenderung merasa dan berperilaku seperti apa yang telah dilabelkan pada mereka.

3. Bentuk diskriminasi yang diterima oleh kedua partisipan dari lingkungan adalah penolakan keluarga (dijauhi keluarga), pemisahan peralatan makan, dikucilkan, dan penolakan dari lingkungan sekitar seperti warga kampung dan lingkungan kerja partisipan. Diskriminasi ini terjadi karena adanya ketakutan lingkungan akan tertular penyakit HIV dan AIDS dan menyebabkan kedua partisipan menarik diri dari lingkungan.

4. Kedua partisipan memiliki pandangan negatif tentang diri sendiri dan merasa tertolak lingkungan sekitar karena sakit yang dideritanya sehingga kedua partisipan memiliki pemikiran negatif, sikap putus asa, depresi, perasaan tertekan dan keinginan mengakhiri kehidupan.

5. Label negatif dan Diskriminasi yang diterima membuat kedua partisipan cenderung memiliki konsep-diri negatif (merasa tidak berharga, tidak berguna, tidak berdaya, menurunnya motivasi untuk menjalani kehidupan dan menarik diri dari lingkungan).

\section{Saran}

Berdasarkan pengalaman dan pertimbangan yang telah diperoleh dari penelitian tentang konsep-diri ODHA yang menerima bentuk label negatif dan diskriminasi dari lingkungan, terdapat saran pada penelitian selanjutnya yang disampaikan berikut ini:

1. Penelitian selanjutnya untuk tema yang sama disarankan untuk melakukan observasi yang lebih mendetail mengenai kehidupan sehari - hari partisipan dan menggali data dari beberapa sumber yang terkait mengenai kondisi partisipan. Tujuannya untuk membandingkan antara informasi yang diberikan partisipan dengan kenyataan sebenarnya sehingga tidak terkesan partisipantif dan data akan lebih akurat.

2. Bagi ODHA diharapkan untuk mengembangkan konsep-diri yang positif seperti mencoba bersosialisasi dengan orang lain dengan cara bergabung dengan LSM (Lembaga Swadaya Masyarakat) yang menangani ODHA, berbagi pengalaman sesama ODHA sehingga dari hal tersebut akan memperoleh pengalaman dan semangat baru untuk tetap melanjutkan hidup.

\section{REFERENSI}

Aztlan. (2009). Anti and pro immigrant entrepreneurs labeling theory revisited. Journal of Chicano Studies, 34, 135-154.

Baron, R.A. dan Donn. B. (2003). Psikologi sosial. Jakarta: Erlangga

Beskow, J. (1990). Depression and suicide. Pharmacopsychiatry, 23, 3-8. doi: 10.1055/s2007-1014522. 
Calhoun, J. F., \& Acocella, J. R. (1978). Psychology of adjustment and human relationships. New York: Random House.

Feather, N. T. (1982). Unemployment and its psychological correlates: A study of depressive symptoms, self-esteem, Protestant Ethic values, attributional style and apathy. Australian Journal of Psychology, 34, 309-323.

Ganengwin, W. (2007) Labeling pada anak. Diunduh dari http://www.sdbinatalenta.com/arsipartikel/artikel_wiwin.pdf pada tanggal 20 Juli 2011. Pukul 02.35 WIB.

Ghufron, M. N dan Rini. R. S. (2010). Teori-Teori Psikologi, Ed. 1, Jogjakarta: Ar-Ruzz Media Group

Gumanti, C. (2007). Analisa faktor-faktor yang mempengaruhi konsep diri pada narapidana remaja di lembaga pemasyarakatan kelas iia tanjung gusta medan. Skripsi tidak diterbitkan. Jurusan Psikologi Fakultas Kedokteran. Universitas Sumatera Utara. Medan

Hurlock. (2004). Psikologi perkembangan sepanjang rentang kehidupan, (ed 5). (Istiwidayanti dan Soedjarwo). Jakarta: Erlangga

Indrawati, P. (2011). Gambaran konsep diri pada narapidana wanita penderita hiv di lembaga pemasyarakatan kelas iia tangerang. Skripsi tidak diterbitkan. Fakultas Psikologi Universitas Paramadina.

Iskandar. (2009). Metodologi penelitian kualitatif (ed 1). Jakarta: Gaung Persada.

KPA (Komisi Penanggulangan AIDS). (2011). Strategi penanggulangan HIV/AIDS. Diunduh 03 Januari 2012 http://www.aidsindonesia.or.id/dasar-hiv-aids

Kessler, R. C., Turner, J., \& House, J. S. (1988). Effects of unemployment oh health in a community survey: Main, modifying, and mediating effects. Journal of Social Issues, 44, 69-85.

Mulyana, D. (2006). Metode penelitian kualitatif: paradigma baru ilmu komunikasi dan ilmu sosial lainnya (ed 5). Bandung: PT. Remaja Rosdakarya.

Mulyati, S. (2010). Hubungan labeling dengan prestasi belajar siswa sma muhammadiyah gubug. skripsi tidak diterbitkan. program studi s1 keperawatan fakultas ilmu kesehatan. Universitas Muhamadiyah Semarang.

Nasution, R. W. (2008). Studi deskriptif tentang faktor konsep diri odha setelah melakukan konseling dan tes hiv di klinik voluntary counseling and testing rsu pirngadi medan. Skripsi tidak diterbitkan. Fakultas Ilmu Sosial dan Ilmu Politik. Universitas Sumatera Utara.

Poerwandari, E. K (2007). Pendekatan kualitatif untuk penelitian perilaku manusia. Jakarta: LPSP3 UI.

Pudjijogyanti, C. (2004). Konsep diri dalam proses belajar mengajar. Jakarta: Pusat Penelitian Unika Atmajaya

Roman, P, dan Trice. H. M. (2000). The sick role, labelling theory and the deviant drinker. International Journal of Social Psychiatry, 34, 245 - 251

Satori, D dan Aan . K. (2011). Metodologi penelitian kualitatif (ed 3). Bandung : Alfabeta

Sheeran, P., \& McCarty, E. (1992). Social structure, self-conception and well-being: An examination of four models with unemployed people. Journal of Applied Social Psychology, 22, 117-113. 
Sinaga, E . S. N. (2007). Konsep diri ODHA (Orang dengan HIV AIDS). Skripsi tidak diterbitkan. Fakultas Komunikasi Universitas Padjajaran.

Sismulyanto. (2010). Dampak confidential ODHA di masyarakat terhadap perilaku ODHA dalam mencegah penularan HIV di kabupaten Banyuwangi. Tesis tidak diterbitkan. Program Pasca Sarjana Universitas Sebelas Maret.

Sarwono, W. S. (2009). Psikologi sosial. Jakarta: Salemba 